\title{
Trend analysis of flood peaks in lower reaches of Satluj River, Himachal Pradesh, India
}

\author{
*Sandeep Kumar ${ }^{1}$, Santosh ${ }^{2}$ \\ ${ }^{1}$ Department of Environment Studies, Panjab University, Chandigarh, India. \\ ${ }^{2}$ Department of Environmental Sciences, MDU, Rohtak (Haryana), India. \\ E-mail address: ssheoran84@gmail.com; ssheoran81@yahoo.co.in
}

Keywords: Flood peaks, Mann-Kendall test, Satluj River Basin, Regression, Trend analysis.

\begin{abstract}
Climate change arising from anthropogenic driven emissions of greenhouse gases has emerged as one of the most important environmental issues in the last two decades. One of the most significant potential consequences of climate change may be alteration in regional hydrological cycle and river flow regimes. Increased temperature is expected to increase the peak flows in snow-fed rivers of Himalayas. The changing pattern of regional temperature on flood peaks deserves urgent and systematic attention over a basin which provides an insight view of historical trends. Lower reaches of Satluj River is selected for the present study. Testing the significance of observed trends in flood peaks has received a great attention recently, especially in connection with climate change. The data series available was 48 years (1967-2010). The records were subjected to trend analysis by using both non-parametric (Mann-Kendall test) and parametric (linear regression analysis) procedures. For better understanding of the observed trends, flood peaks were computed into standardised flood peak indices (SFPI). These standardised data series were plotted against time and the linear trends observed were represented graphically. The analysis of flood peaks at different observation stations in lower reaches of Satluj River showed a large variability in the trends and magnitudes. The trend analysis results of flood peaks and gauge heights indicate that the flood peaks at all sites i.e. Rampur, Suni and Kasol show increasing but statistically insignificant trends. The trends in gauge height at all sites are also showing increasing trend but Kasol is statistically significant at $95 \%$ confidence level. The fast melting of glaciers, incessant monsoon rainfall and the synchronisation of the discharge peaks are the main causes of river floods. The past flood peaks will help us to observe the frequency of occurrence of floods in certain region and to determine whether the flood peaks in the past have been same with that of the present or whether there is any deviation in the trend in relation to climate change. Such studies will help in designing mitigation and adaptation strategies towards extreme hydrological events.
\end{abstract}

\section{INTRODUCTION}

Climate change arising from anthropogenic driven emissions of greenhouse gases has emerged as one of the most important environmental issues in the last two decades. Information about impacts of climate change is required at global, regional and basin scales for a variety of purposes. The spatial distribution and magnitude of temperature trends would help in obtaining climate change scenarios. It may have implications on various environmental variables. The consequences of climate change on Indian sub-continent, especially the mountainous regions are poorly understood. Its impacts will have significant effect on the northwest region of India. The Himalayan region has large and intricate network of river systems which is reinforced by the snowmelt, glaciermelt and rainfall. Many of major rivers originating in this region have their upper catchments covered by snow/glacier. The altitude and climatic change induced precipitation variability are expected to play major role on discharge pattern of snow-fed rivers of Himalayas, coupled with an increase in peak flows.

An understanding of the hydrological response of a river basin under changing climatic conditions will help to resolve potential issues associated with hydro-meteorological disasters and availability of water for agriculture, industry, hydropower, domestic use etc. The changing pattern 
of discharge and flood peaks deserves urgent and systematic attention over a basin which provides an insight view of historical trends. Therefore, information on trend analysis over a basin scale is of utmost importance for planning, development and utilisation of water resources. Trend analysis has proved to be useful tool for effective water resources planning, design and management since trend detection of hydrological variables provides a useful information on the possibility of change in tendencies of the variables in future (Hamilton et al., 2001; Yue and Wang, 2004).

The intensive human activities, including reservoir construction, hydropower development and water abstraction have become more serious issues from the upper to the lower part of the Satluj River Basin. These have substantially changed the hydrology of the river. Extreme climatic events often cause catastrophic damage to nature and human society. Therefore, regional assessments of various climates and geographic regions are needed for understanding the uncertainties of the changing trends for extreme climatic events (Li et al., 2010). One of the most significant potential consequences of climate change may be alteration in regional hydrological cycle and river flow regimes. Necessity of the hour is to concentrate on the studies, how the possible climate change will affect the intensity, temporal and spatial variability of flood peaks in river basins.

Therefore, one large catchment (Satluj) is selected for the present study. Most of the flow in its upper mountain basin is derived from the melting of snow and glaciers. Climatic variability and change in precipitation pattern will affect the flooding pattern in the river. The changes in the amount and seasonal distribution of precipitation have potentially serious implications for the hydrological regimes of catchment area. The nature of climate change and its impact on the hydrology of the Satluj River Basin have been studied inadequately because of inaccessibility, terrain ruggedness and sparse network of gauge stations. The present study tries to fill this vacuum by studying the trend analysis of flood peaks.

Testing the significance of observed trends in hydrological and meteorological time series has received a great attention recently, especially in connection with the assessment of observed changes in the natural and human environment due to global warming. This is reflected by a huge number of studies carried out over the last three decades, dealing with the assessment of significance of trends in flood peaks.

Changes in flood frequencies are expected at some locations, particularly in northern latitudes and in catchments experiencing snowmelt flooding events (Burn and Hag Elnur, 2002). The spatial and temporal patterns in the annual maximum and minimum water level in the Pearl River Delta (PRD) region were studied by Zhang et al. (2009). There is no obvious trend for the annual maximum water level in the upper region, while the stations in the middle region exhibit an increasing trend and this upward trend is significant in the lower region. Some stations in the upper part showed increasing trend for the annual extreme runoff. Apart from the climatic changes, human activities are also responsible for the temporal and spatial variability of annual extreme water levels. Peak flows due to rainfall events in the summer are increasing, as well as the number of days with higher flows are increasing (Novotny and Stefan, 2007).

A sensitivity study by Cunderlik and Simonovic (2005) for a catchment in Ontario, Canada, projected a decrease in snowmelt induced floods, while an increase in rain induced floods is anticipated. The variability of annual maximum flow is projected to increase. For the recent global warming of the $20^{\text {th }}$ century, no general and coherent trends could be observed with regard to increases in annual maximum flows (Kundzewicz et al., 2005). However, the increasing risk of floods was detected in 29 basins larger than $20,000 \mathrm{Km}^{2}$ (Milly et al., 2002). Yet, in some highly vulnerable regions, a significant increase in flooding probabilities has been found under global warming (Mirza, 2002). The variability in extreme discharges for climate change conditions increases with respect to the simulations for current climate conditions. The total uncertainty in river flooding with climate change is much larger than the change with respect to current climate conditions (Booij, 2004).

The future climate would be wetter and warmer than the present climate affecting the type, magnitude and temporal distribution of floods as well as the frequency of flood peaks (Loukas $e t$ 
$a l ., 2004)$. The frequency of great floods increased substantially during the twentieth century. The recent emergence of a statistically significant positive trend in risk of great floods is consistent with results from the climate model, and the model suggests that the trend will continue (Milly et al., 2002). Peak flow in the rivers is likely to move from spring to winter in many areas due to early snowmelt, with lower flows in summer and autumn. Glacier retreat is likely to continue and many small glaciers may disappear in future. Rapid melting of glaciers can lead to flooding of rivers and to the formation of glaciermelt water lakes which may pose a serious threat of outburst floods (Coudrain et al., 2005). There is increase in frequency and intensity of extreme hydrometeorological events (Viviroli et al., 2010).

Annual peak flood discharges in the Satluj and Chenab Basins showed significant increasing trends; significant decreasing in Beas River and insignificant trend in Ravi River. Notwithstanding these variations, there is increase in the number of high magnitude flood events in the northwestern Himalaya Rivers during the last three decades. The results of the trend analysis of Standardised Discharge Indices (SDI) of annual peak flood discharges of the four rivers of the North Western Himalayas $(\mathrm{NWH})$ show that the Satluj and Chenab rivers reveal significant increasing trends while Ravi and Beas show insignificant increasing and significant decreasing trends respectively, at 95\% confidence level. This means that only the Satluj and Chenab appear to have a response matching with the variation in temperature (Bhutiyani et al., 2008). Jiang et al. (2007) concluded a positive trend in flood discharges in most of stations in the Yangtze River Basin, China.

\section{STUDY AREA}

The Satluj River (Vedic name - Satudri and Sanskrit name - Shatadru), also known as the Langqên (Chinese) and Sutlej (Indian), is the principal and easternmost tributary of the Indus River system. The basin area falls in Lahaul \& Spiti, Kinnaur, Shimla, Kullu, Mandi, Solan and Bilaspur districts of Himachal Pradesh. The geographical limits of area lie between $30^{\circ} 45^{\prime} \mathrm{N}$ to $33^{\circ} 00^{\prime} \mathrm{N}$ latitudes and $76^{\circ} 15^{\prime} \mathrm{E}$ to $79^{\circ} 00^{\prime} \mathrm{E}$ longitudes in the western Himalayas (Figure 1). The total catchment area of Satluj River, from origin to Bhakra dam, is about 56,875 km (21,960 Sq. miles). The upper part of river basin is considerably wider than the lower one. In Himachal Pradesh, Satluj Basin has catchment area of $20,398 \mathrm{Km}^{2}$ which is $30.7 \%$ of the total catchment area of river systems (SCST \& E, 2006). Indian part of river up to Bhakra Dam is elongated in shape and covers the part of outer (Shiwalik range), middle (Dhauladhar range) and greater Himalayas (Zaskar range).

Satluj River originates from the southern slopes of Kailash Mountains i.e. from Rakas Lake, near the Mansarovar Lake as Longcchen Khabab River at an elevation of about 4,572 $\mathrm{m}$ (15,000 ft), above msl. Total length of river is approximately $1,448 \mathrm{~km}(320 \mathrm{Km}$ in China, $758 \mathrm{Km}$ in India and $370 \mathrm{Km}$ in Pakistan). It enters India from East of Shipki La (altitude $-3,048 \mathrm{~m}$, above msl) after traversing a length of about $320 \mathrm{~km}$ (200 miles) in the Tibetan province of Nari Khorsam, through a narrow gorge in the Kinnaur district of Himachal Pradesh and flows in southwesterly direction. The river is supported by a number of mighty tributaries on either side. Main tributaries are Spiti, Baspa and Gambhar at Khab, Karchham and Kangri at an elevation of 2,600, 1,750 and $450 \mathrm{~m}$ above msl respectively. Near Rampur, it crosses the Dhauladhar range and then traverses through a series of successive Shiwalik ranges. Before leaving the Himachal Pradesh, it cuts a gorge in Naina Devi Dhar and mingles with the water of Govind Sagar Lake. It enters the plains of Punjab near Bhakra where Asia's one of the highest gravity multipurpose dam (Capacity to generate electricity $-1,325$ MW and height - $740 \mathrm{ft} / 225.55 \mathrm{~m}$ ) has been constructed. It finally drains into the main Indus River in Pakistan.

Based on the amount of annual precipitation and the variation in temperature, the study area, from North to South, has been divided into three broad climatic zones (Figure 2). Each zone is characterised by its own peculiarities of climatic factors, geomorphic and topographic features (Gupta et al., 1994; Bartarya et al., 1996):

1. Semi-arid to arid temperate zone (Cold desert) - This zone lies in the upper Satluj Valley, upstream from Morang. Towards North of Morang, the cold desert conditions prevail which 
are characterised by very low monsoonal precipitation, high speed of cold winds and the precipitation generally occurs in the form of snowfall during winter season.

2. Sub-humid to humid temperate zone - This zone covers the middle Satluj Valley between the Wangtu and Morang. It is the transitional zone which receives low rainfall during the monsoon period and moderate to heavy snowfall in the higher reaches during winter.

3. Wet temperate or Monsoonal zone - It lies in the lower Satluj Valley downstream of Wangtu. This zone is under the great influence of monsoonal winds and receives heavy rainfall during rainy season from mid June to mid September.

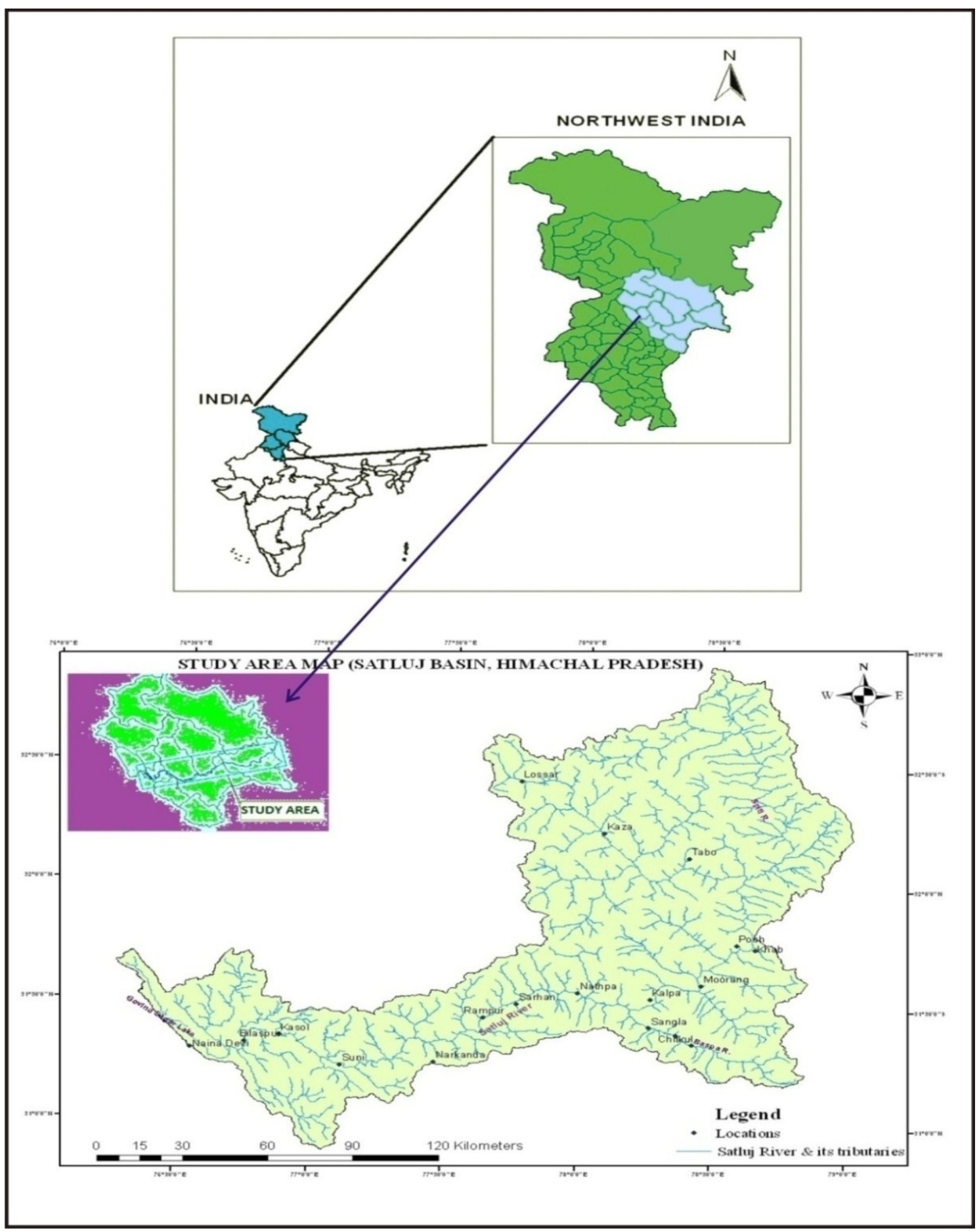

Figure 1. Schematic showing the study area map of Satluj River Basin upto Bhakra Dam, Himachal Pradesh. 


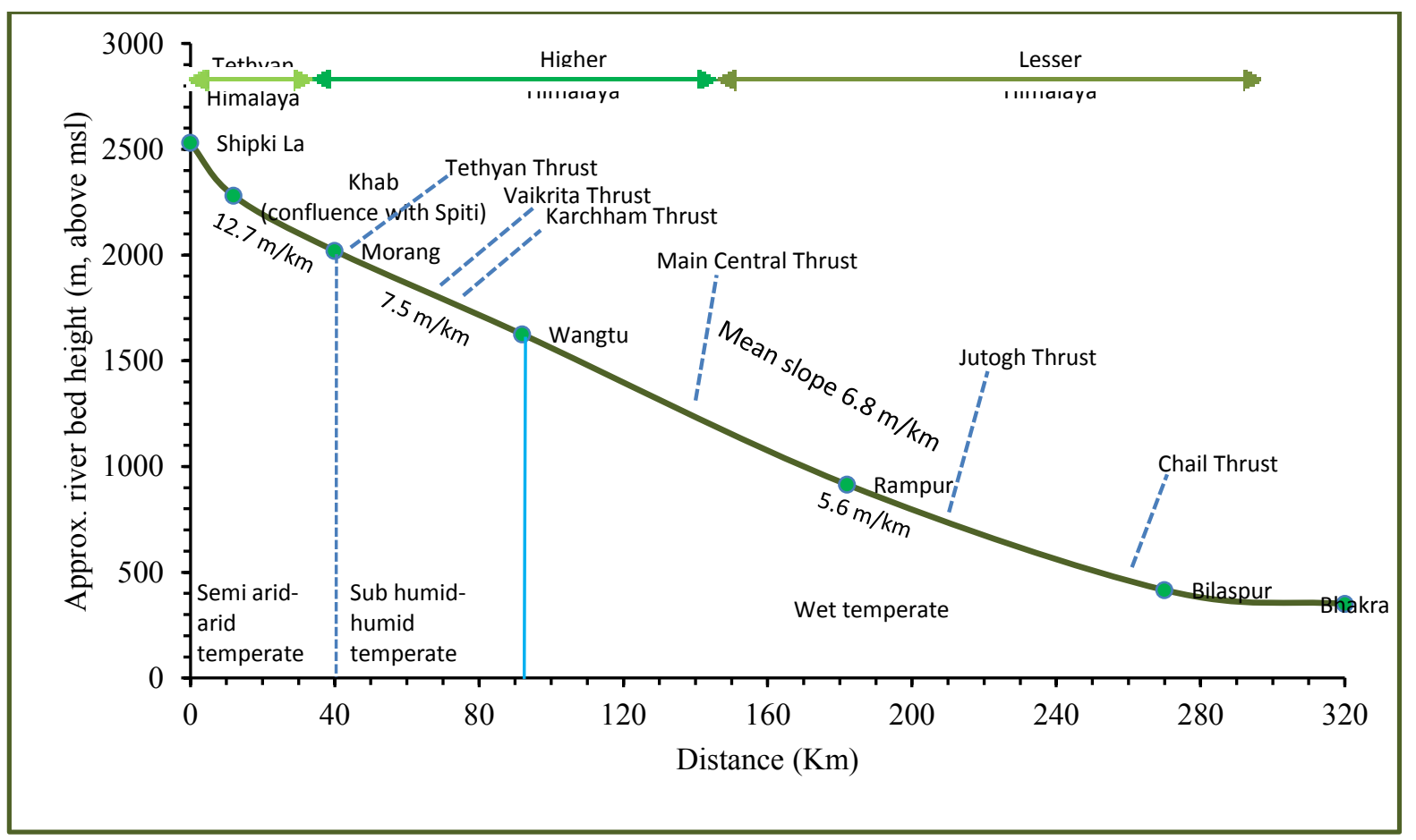

Figure 2. Longitudinal profile of Satluj River from Shipki La to Bhakra Dam. Three climatic zones are demarcated along with the major thrusts.

The fall of Satluj from its source to the plain areas is very uniform. A gross fall of $2,180 \mathrm{~m}$ is available in the river bed from Shipki La to Bhakra in a length of about $320 \mathrm{Km}$ (Figure 2). The altitude in the study area increases from West to East and South to North. Based on broad climatic conditions, the Satluj River Basin has following four seasons: Winter (December to March), Premonsoon (April to June), Monsoon (July to September), Post-monsoon (October, November).

\section{MATERIALS AND METHODS}

For the considered study area, records of flood peaks and gauge heights were subjected to trend analysis by Mann-Kendall and regression coefficient test. In order to determine the degree and rate of change in such variables, long-term data sets are required. Burn and Elnur (2002) stated that a minimum record length of 25 years ensures validity of the trend results statistically. The present analytical study on the spatial and temporal trends is based on the available hydrological data from Bhakra Beas Management Board (BBMB), Nangal. The trends were identified by investigating the time series of different observation stations distributed over the lower reaches of Indian part of Satluj River. Data was scarce especially in the upper catchment area because of inadequate hydrometeorological networks in the high altitude regions with rugged terrain and poor accessibility. The data length available was 48 years for flood peaks (cumecs) and gauge heights (Feet).

In order to investigate trends in time series, observational records were prepared. For flood peaks, the data series were directly available. To bring uniformity and facilitate comparison, standardised flood peak indices (SFPI) can be computed by subtracting the mean and dividing by the standard deviation of discharge data series. The SFPI data series are then subjected to trend analysis by statistical techniques (Pant and Rupakumar, 1997; Shreshtha et al., 2000; Bhutiyani et al., 2008). These standardised time series data were plotted against time and the linear trends observed were represented graphically. The linear trend values, represented by the slope of a simple least square regression line with time as independent variable gave the magnitude of rise or fall. Univariate (flood peaks and gauge height) as well as multivariate (annual and monsoonal discharge vs flood peaks) trends were studied.

The location (longitude and latitude) and altitude of flood peak observation sites are shown in Table 1 and figure 3. The altitude of the hydro-meteorological stations varied from 809 to 1,302 m. 
Table 1. Flood peak data availability in Satluj River Basin.

\begin{tabular}{|l|l|l|}
\hline \multicolumn{1}{|c|}{ Station } & \multicolumn{1}{c|}{ Latitude and longitude } & \multicolumn{1}{c|}{ Elevation (m) } \\
\hline Rampur & $31^{\circ} 27^{\prime} 15^{\prime \prime} \& 77^{\circ} 38^{\prime} 40^{\prime \prime}$ & 1,302 \\
\hline Suni & $31^{\circ} 14^{\prime} 15^{\prime \prime} \& 77^{\circ} 06 ' 30^{\prime \prime}$ & 843 \\
\hline Kasol & $31^{\circ} 21^{\prime} 25^{\prime \prime} \& 76^{\circ} 52^{\prime} 42^{\prime \prime}$ & 809 \\
\hline
\end{tabular}

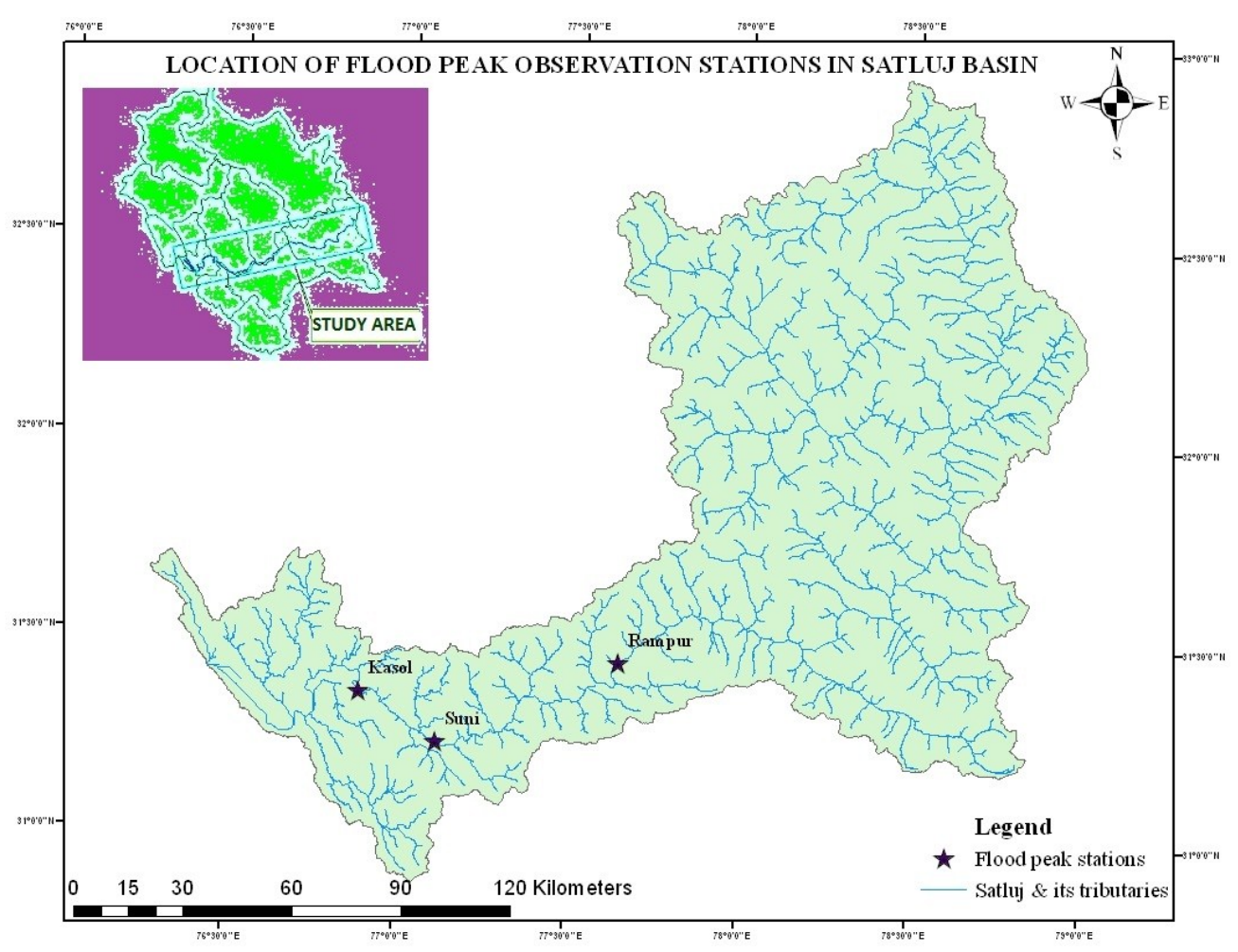

Figure 3. Location of flood peak observation sites in lower reaches of Satluj River Basin.

In order to investigate the trends, several statistical techniques are currently available. In the present study, trend analysis have been made by using both non-parametric (Mann-Kendall test) and parametric (linear regression analysis) procedures. Parametric tests assume that the random variable is normally distributed and homo-sedastic (homogeneous variance). Non-parametric tests make no assumption for probability distribution. The purpose of trend analysis is to determine if the values of a random variable generally increase (or decrease) over some period of time in statistical terms (Helsel and Hirsch, 1992).

\subsection{Mann-Kendall test}

The non-parametric tests are more suitable for non-normally distributed, censored data, including missing values which are frequently encountered in hydro-meteorological time series (Hirsch and Slack, 1984; Yue and Pilon, 2004). The Mann-Kendall trend test has therefore been widely used for testing trends in many natural time series that deviate significantly from the Normal distribution, such as temperature. The MK test was found to be an effective tool for identifying trends in hydrologic and other related variables, resistant to the effect of extreme values (Hirsch et al., 1982; Burn, 1994). This test has been applied to temperature, precipitation and stream flow data series (Yu et al., 1993; Douglas et al., 2000; Yue et al., 2003; Burn et al., 2004). The MK test applied in this study is a rank based method for evaluating the presence of trends in time series data, without specifying whether the trend is linear or nonlinear.

To identify the trends in the climatic variables with reference to climate change, the nonparametric Mann-Kendall test (Mann, 1945; Kendall, 1975) has been applied in hydrometeorological data. Mann originally used this test and Kendall subsequently derived the test for 
statistical distribution. The co-variances between Mann-Kendall statistics were proposed by Dietz and Kileen (1981) and the test was extended in order to include seasonality (Hirsch and Slack, 1984). The test compares the relative magnitudes of sample data rather than the data values themselves (Gilbert, 1987). In the present study, test was applied to mean temperature for determining monotonic trends.

The MK test has two parameters i.e. significant level, indicates the trend's strength and the slope magnitude, indicates the direction as well as magnitude of the trend. The data values are evaluated as an ordered time series. Each data value is compared to all subsequent data values. The initial value of the Mann-Kendall statistic, $\mathrm{S}$, is assumed to be 0 (e.g., no trend). If a data value from a later time period is higher than a data value from an earlier time period, $\mathrm{S}$ is incremented by 1 . On the other hand, if the data value from a later time period is lower than a data value sampled earlier, $\mathrm{S}$ is decremented by 1 . The net result of all such increments and decrements yields the final value of $\mathrm{S}$. A very high positive value of $\mathrm{S}$ is an indicator of an increasing trend and a very low negative value indicates a decreasing trend. However, it is necessary to compute the probability associated with $\mathrm{S}$ and the sample size, $\mathrm{n}$, to statistically quantify the significance of the trend. So, the MK test considers only the relative values of all terms in the series $X=\left\{\mathrm{x}_{1}, \mathrm{x}_{2}, \ldots, \mathrm{x}_{\mathrm{n}}\right\}$ to be analysed. The Mann-Kendall statistic $\mathrm{S}$ which is the sum of the differences between the data points is defined as (Salas, 1992)

$$
S=\sum_{i=1}^{N-1} \sum_{j=i+1}^{N} \operatorname{sgn}\left(x_{j}-x_{i}\right)
$$

where $x_{i}$ and $x_{j}$ are the sequential data values and $n$ is the number of data points. Let $x_{j}-x_{i}=\theta$.

The value of sign $(\theta)$ is computed as

$$
\operatorname{sgn}(\theta)=\left\{\begin{array}{cl}
1 & \text { if } \quad \theta>1 \\
0 & \text { if } \theta=1 \\
-1 & \text { if } \quad \theta<1
\end{array}\right.
$$

For large samples ( $\mathrm{n}>10)$, the test is conducted using a normal distribution (Helsel and Hirsch, 1992) with mean E(S) and variance Var (S). Kendall (1975) obtained the theoretical mean and variance of $S$ under the assumption of no trend as:

$$
\begin{gathered}
\mathrm{E}(S)=0 \\
\operatorname{Var}(S)=\frac{1}{18}(N(N-1)(2 N+5) \\
\left.-\sum_{k=1}^{n} t_{k}\left(t_{k}-1\right)\left(2 t_{k}+5\right)\right),
\end{gathered}
$$

where $t_{k}$ is the extent of any given tie (number of $x$ 's involved in a given tie), and $\Sigma t_{k}$ denotes the sum of the terms $t_{k}\left(t_{k}-1\right)\left(2 t_{k}+5\right)$ which are evaluated and summed for each tie of the $t_{k}$ number in the data. The standard normal variable $Z$ is computed by:

$$
Z=\left\{\begin{array}{ccc}
\frac{S-1}{\sqrt{\operatorname{Var}(S)}} & \text { if } & S>0, \\
0 & \text { if } & S=0, \\
\frac{S+1}{\sqrt{\operatorname{Var}(S)}} & \text { if } & S<0 .
\end{array}\right.
$$


Compute the probability associated with this normalised test statistic. The trend is said to be decreasing if $\mathrm{Z}$ is negative and the computed probability is greater than the level of significance. If the q-value is less than or equal to the significance level then it is correct to reject the null hypothesis that a trend does not exist in the data set. The trend is said to be increasing if the $\mathrm{Z}$ is positive and the computed probability is greater than the level of significance. If the computed probability is less than the level of significance, there is no trend. If the computed value of $|\mathrm{Z}|>\mathrm{z}$ $\alpha / 2$, the null hypothesis $H_{0}$ of having no trend in the data series is rejected at $\alpha$ level of significance in a two-sided test. Thus, in a two-tailed test for trend, the null hypothesis, that there is no trend in the dataset, is either rejected or accepted depending on whether the calculated $\mathrm{Z}$ statistics is more than or less than the critical value of Z-statistics obtained from the normal distribution table at 5\% significance level. Significance levels (p-values) for each trend test can be obtained as:

$$
\mathrm{p}=2[1-\Phi|\mathrm{Z}|]
$$

where $\Phi$ denotes the cumulative distribution function (cdf) of a standard normal variant.

\subsection{Pre-Whitney}

However, a basic assumption for the original Mann-Kendall test is that the data should be random and identically distributed which is seldom the case in natural time series. It has been long known (Cox and Stuart, 1955) that positive serial correlation among the observations would increase the chance of a significant answer even in the absence of a trend. The presence of serial correlation can complicate the identification of trends that a positive serial correlation can increase the expected number of false positive outcomes for MK test (Von Storch and Navarra, 1995). So, before applying the MK test, the data series was tested for serial correlation. In order to limit the influence of serial correlation, pre-whitening was proposed by Von Storch (1995). Bayazit and Önöz (2007) suggested that pre-whitening should be avoided when the test has a high power, the slope of trend is high, and the sample size is large (i.e., $\mathrm{n} \geq 50$ ).

In present study, Mann-Kendall test was used in conjunction with the widely used method of pre-whitening. If the lag -1 auto-correlation $r_{1}$ was found to be non-significant at $95 \%$ confidence level, then the MK test was applied directly to the original data series $\mathrm{x}_{1}, \mathrm{x}_{2}, \ldots, \mathrm{x}_{\mathrm{t}}$. Otherwise, the test was applied to the pre-processed data series $\mathrm{x}_{2}-\mathrm{r}_{1} \mathrm{x}_{1}, \mathrm{x}_{3}-\mathrm{r}_{1} \mathrm{x}_{2}, \ldots, \mathrm{x}_{\mathrm{t}}-\mathrm{r}_{1} \mathrm{x}_{\mathrm{t}-1}$ referred to as 'prewhitened' (Von Storch and Navarra, 1995; Partal and Kahya, 2006). The pre-whitening removes serial correlation from the data by means of the following formula:

$$
\mathrm{X}_{\mathrm{t}}^{\prime}=\mathrm{x}_{\mathrm{t}}-\mathrm{r}_{1} \mathrm{x}_{\mathrm{t}-1}
$$

where $\mathrm{x}_{\mathrm{t}}$ is the original time series value for time interval $t, X_{t}^{\prime}$ is the pre-whitened time series value and $r_{1}$ is the lag -1 autocorrelation coefficient that can be expressed as:

$$
r_{1}=\frac{\frac{1}{n-1} \sum_{t=1}^{n-1}\left[X_{t}-E\left(X_{t}\right)\right]\left[X_{t+1}-E\left(X_{t}\right)\right]}{\frac{1}{n} \sum_{t=1}^{n}\left[X_{t}-E\left(X_{t}\right)\right]^{2}}
$$

where $\mathrm{E}\left(\mathrm{x}_{\mathrm{t}}\right)$ is the mean of the sample data. Von Storch and Navarra (1995) also demonstrated that pre-whitening operation is not necessary for $\mathrm{r}_{1} \leq 0.1$.

\subsection{Regression}

The changes in flood peaks were plotted against time and the trend was examined by fitting the linear regression line. Linear regression analysis indicates the tendency rate (slope) using least squares at the $95 \%$ confidence level, indicates the mean temporal change of the studied variable. Positive values of the slope show increasing trends, while negative values indicate decreasing trends. The total change during the period under observation is obtained by multiplying the slope with the number of years (Tabari and Marofi, 2010; Tabari et al., 2010a, b). The parametric test considers the linear regression of the random variable $\mathrm{Y}$ on $\mathrm{X}$, expressed as:

$$
Y=\beta_{0}+\beta_{1} X+\varepsilon
$$




\section{Results and discussion}

The analysis of flood peaks of different observation sites in the basin showed a large variability in the trends and magnitudes. Figures (4-12) and Tables 2 show the results of trend analysis of flood peaks and gauge height at lower region of the river basin, for time-span of 48 years (1963-2010). Investigation of the relationship between trends in hydrological variables was also carried out i.e. annual as well as monsoonal discharge and flood peaks.

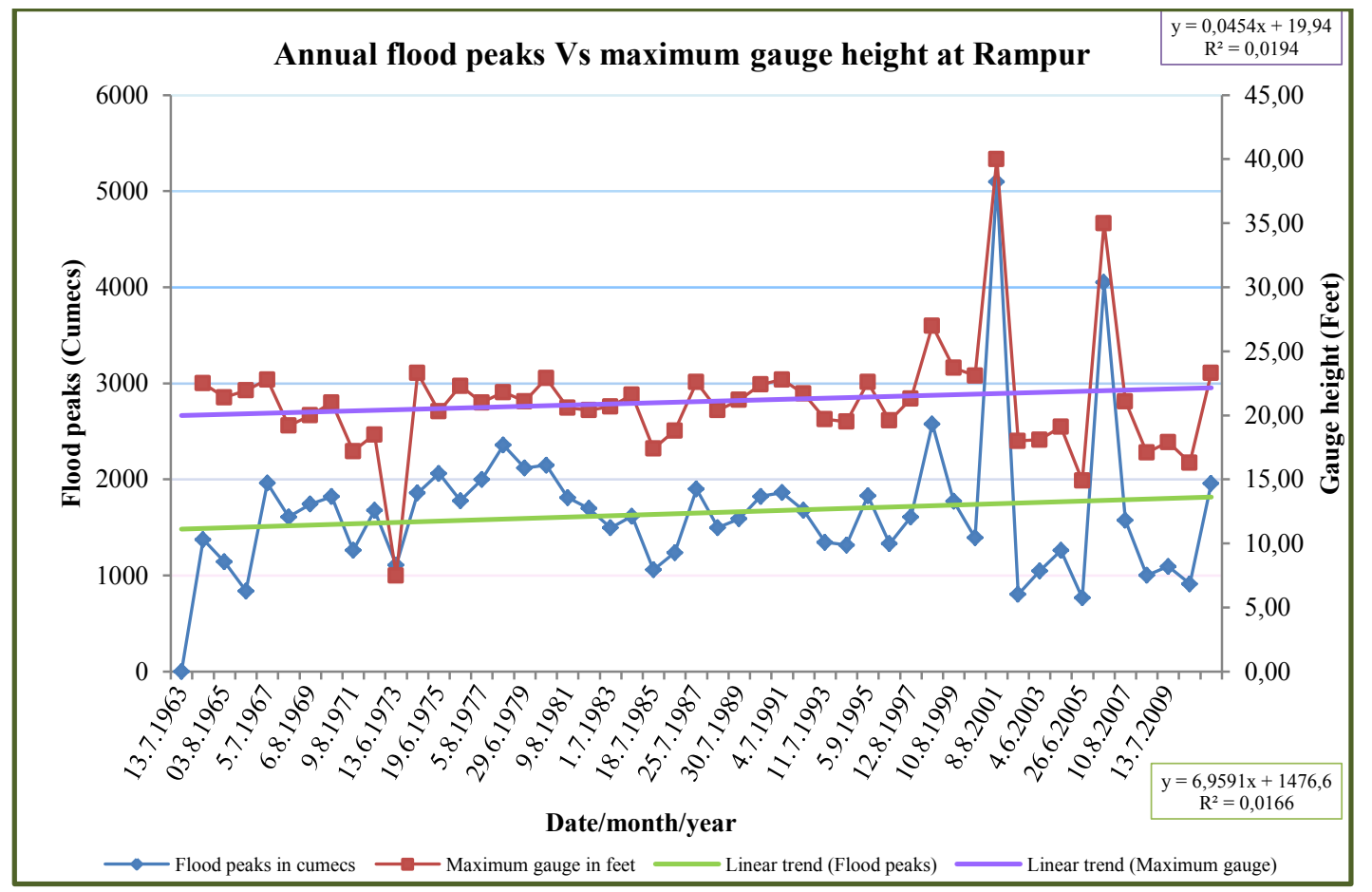

Figure 4. Time series plot for annual flood peaks and maximum gauge height at Rampur.

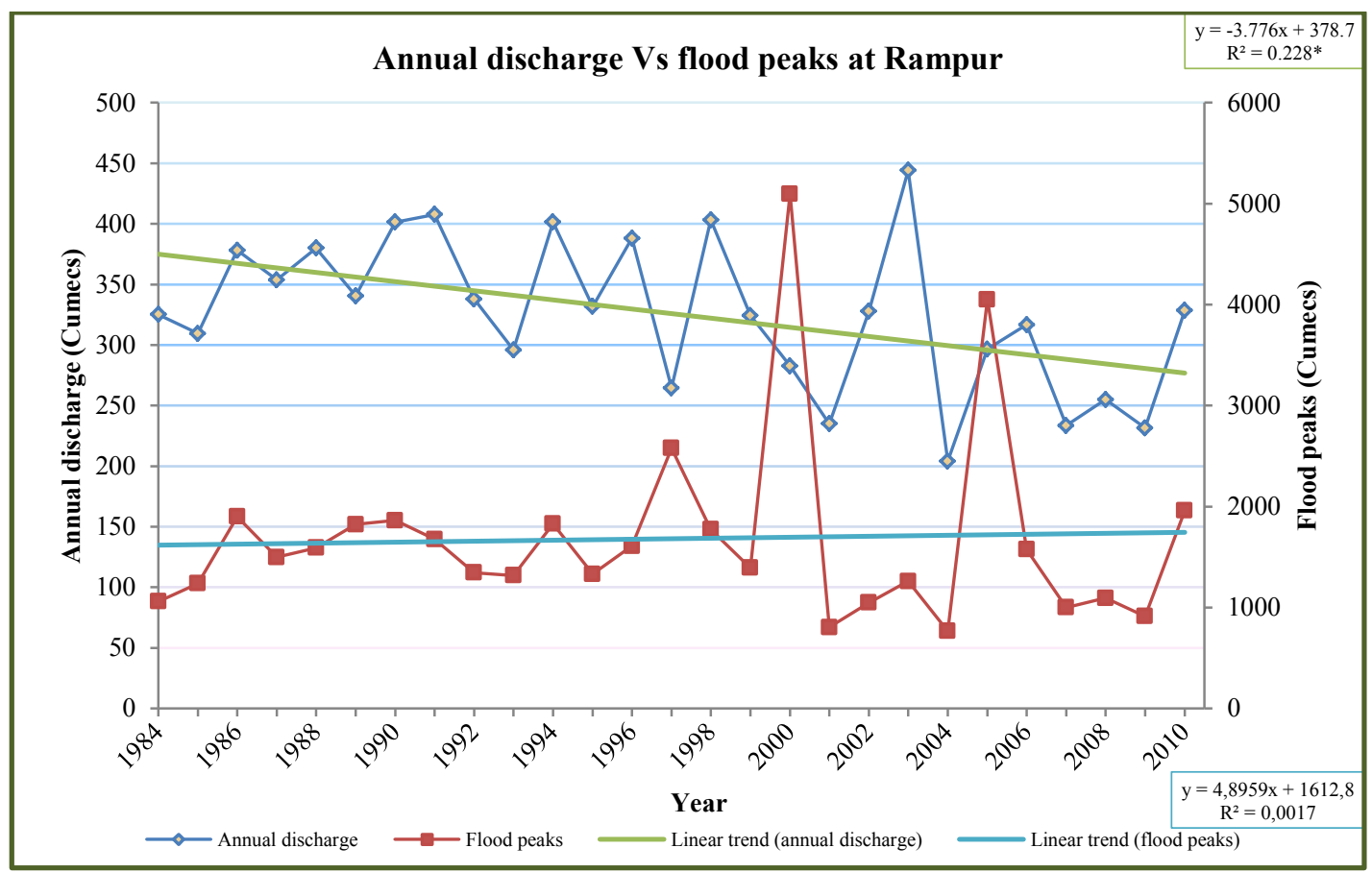

Figure 5. Comparison of annual discharge with flood peaks at Rampur $\left({ }^{*}\right.$ Significant at $95 \%$ confidence level). 


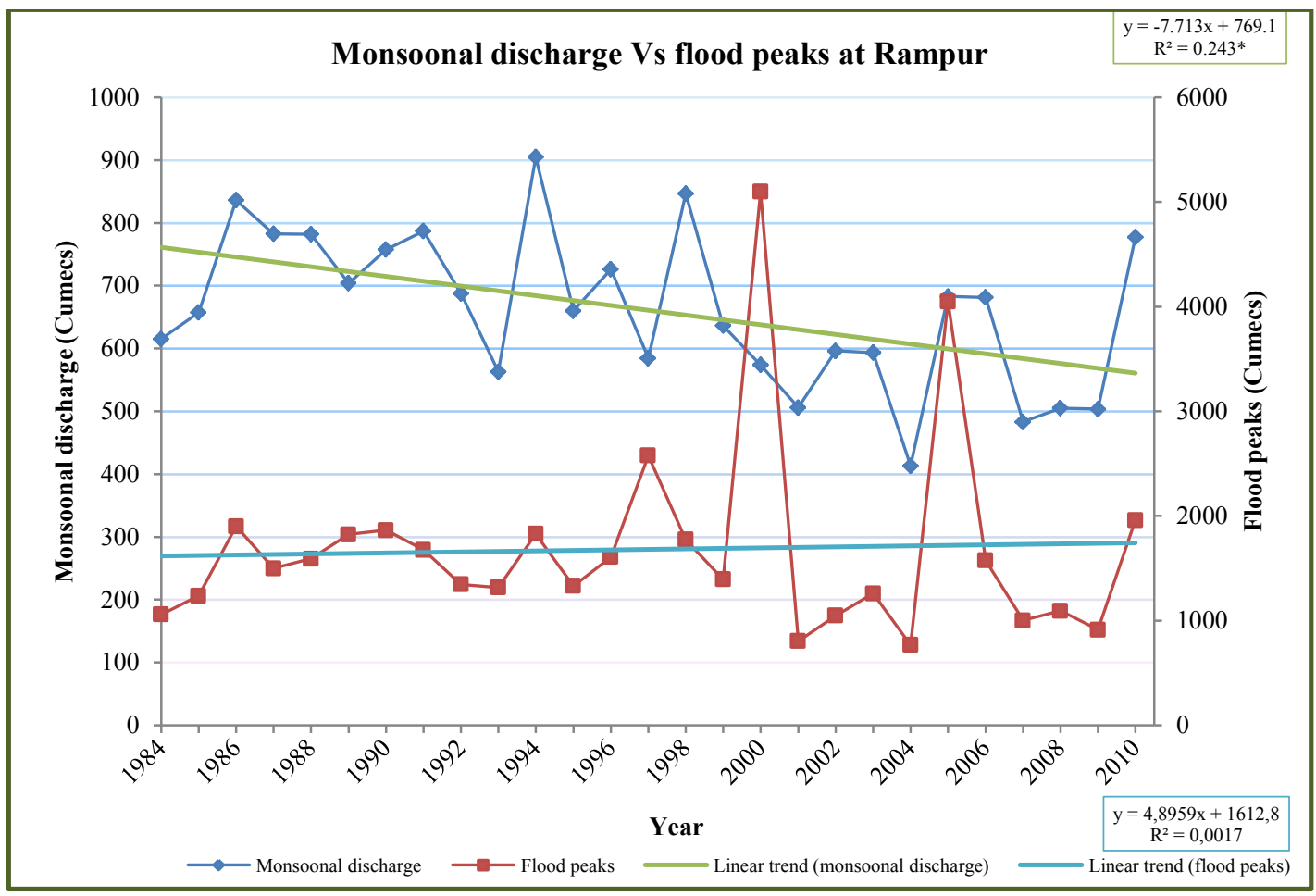

Figure 6. Comparison of monsoonal discharge with flood peaks at Rampur (*Significant at $95 \%$ confidence level).

The analysis at Rampur site of Satluj River (Figure 4-6) shows that flood peaks and gauge heights are corresponding to each other and have increasing but statistically insignificant trends. A comparison of annual and monsoonal average discharge with flood peaks was done. Annual average discharge shows the decreasing trend which is statistically significant, while increasing but statistically insignificant trend was shown by flood peaks. Similarly, monsoonal average discharge shows the statistically significant decreasing trend, while the flood peak analysis indicates increasing but statistically insignificant trend.

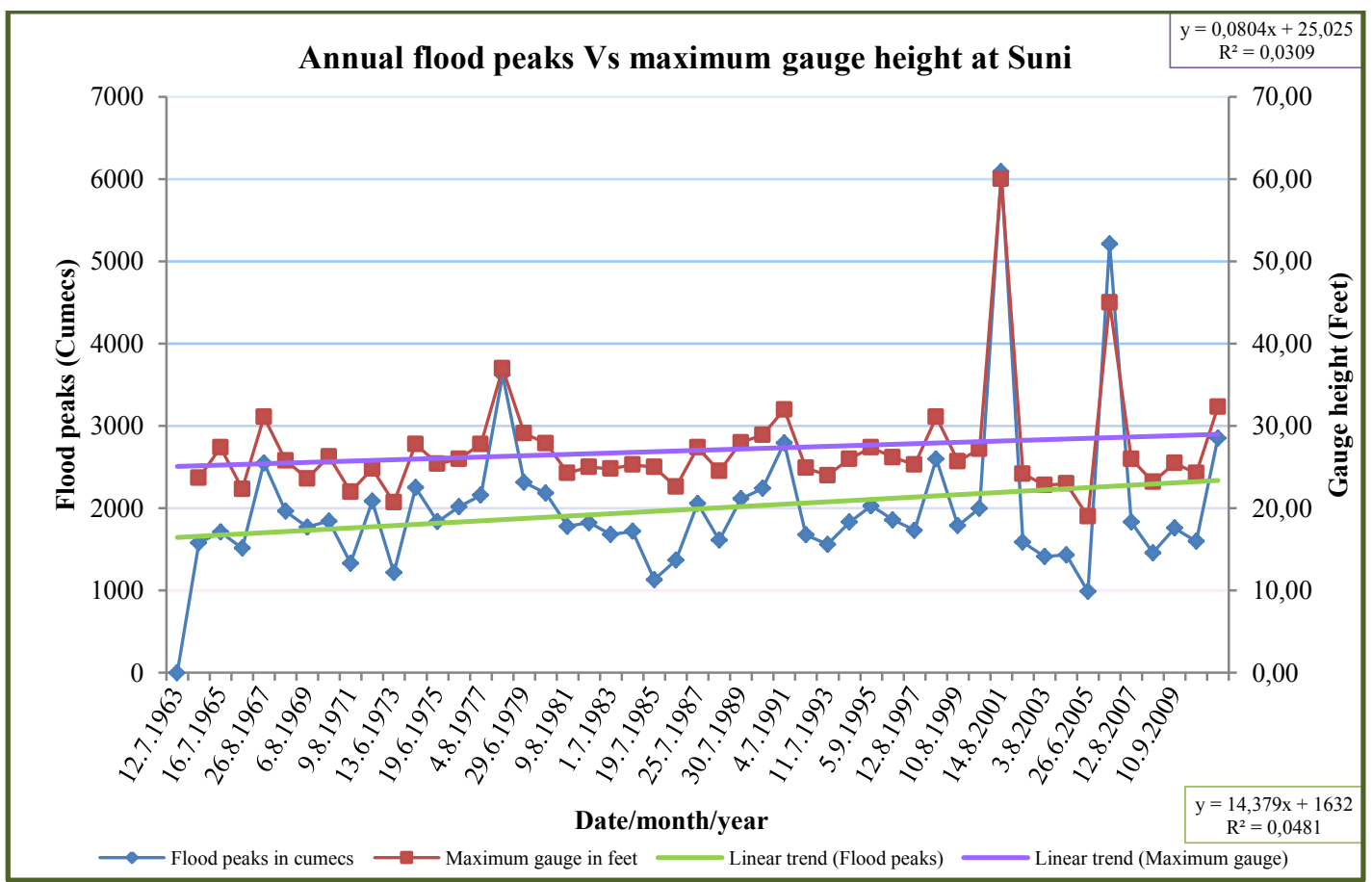

Figure 7. Time series plot for annual flood peaks and maximum gauge height at Suni. 


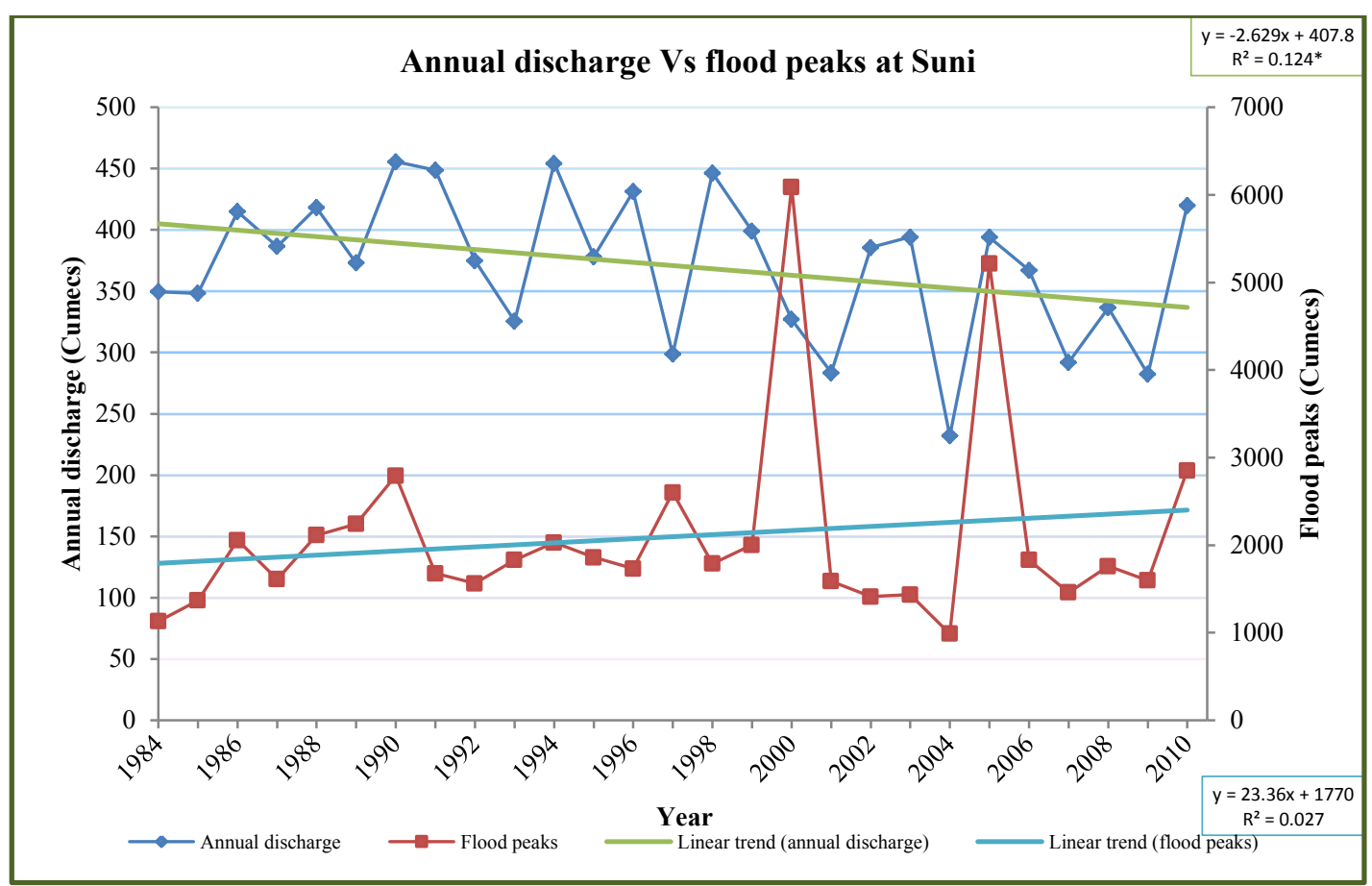

Figure 8. Comparison of annual discharge with flood peaks at Suni (*Significant at $95 \%$ confidence level).

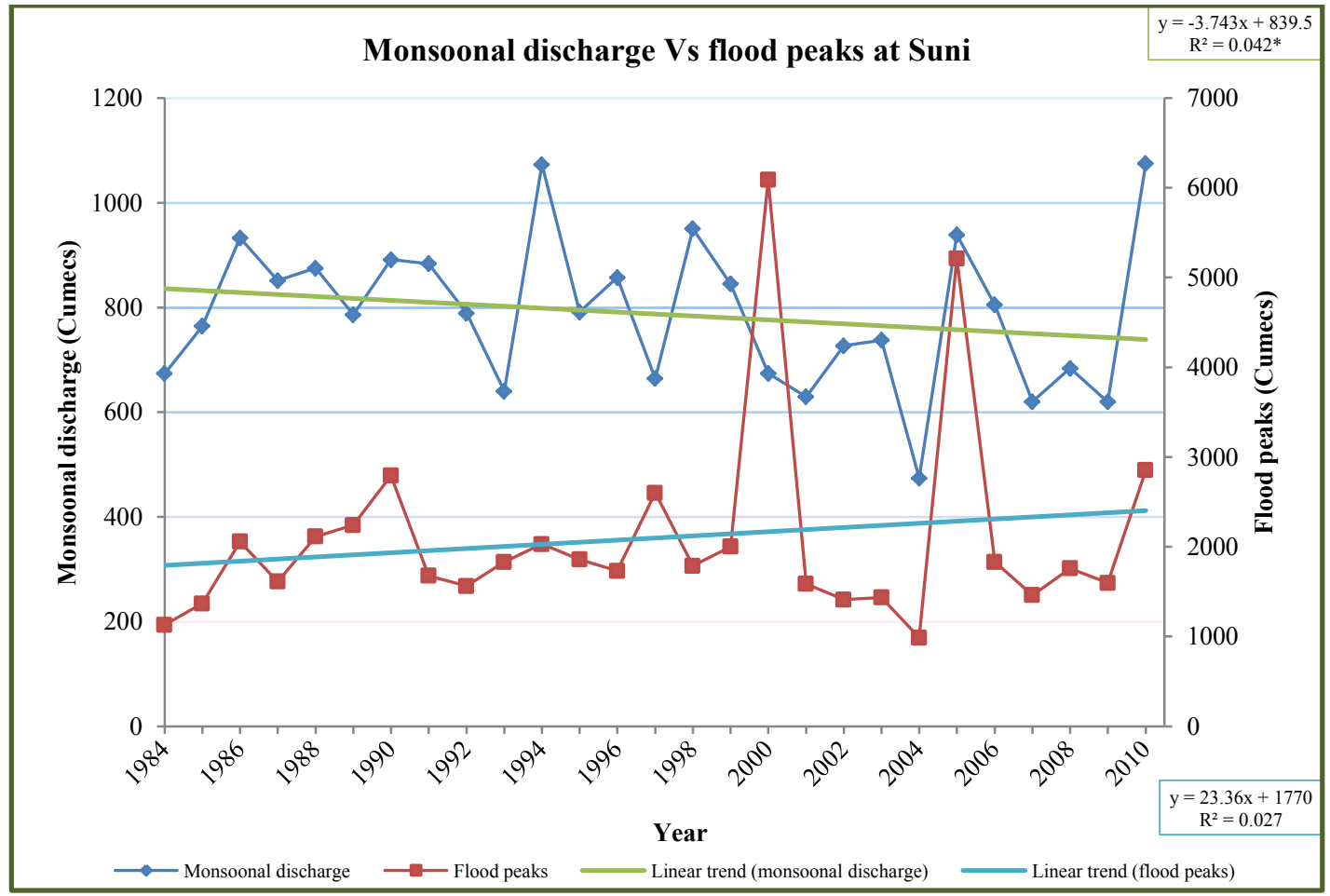

Figure 9. Comparison of monsoonal discharge with flood peaks at Suni (*Significant at $95 \%$ confidence level).

The analysis at Suni site of Satluj River (Figure 7-9) shows that flood peaks and gauge heights are corresponding to each other and have increasing but statistically insignificant trend. A comparison of annual and monsoonal average discharge with flood peaks was done. Annual average discharge shows the decreasing trend which is statistically significant, while increasing but statistically insignificant trend was shown by flood peak. Similarly, monsoonal average discharge shows the statistically significant decreasing trend, while the flood peak analysis indicates increasing but statistically insignificant trend. 


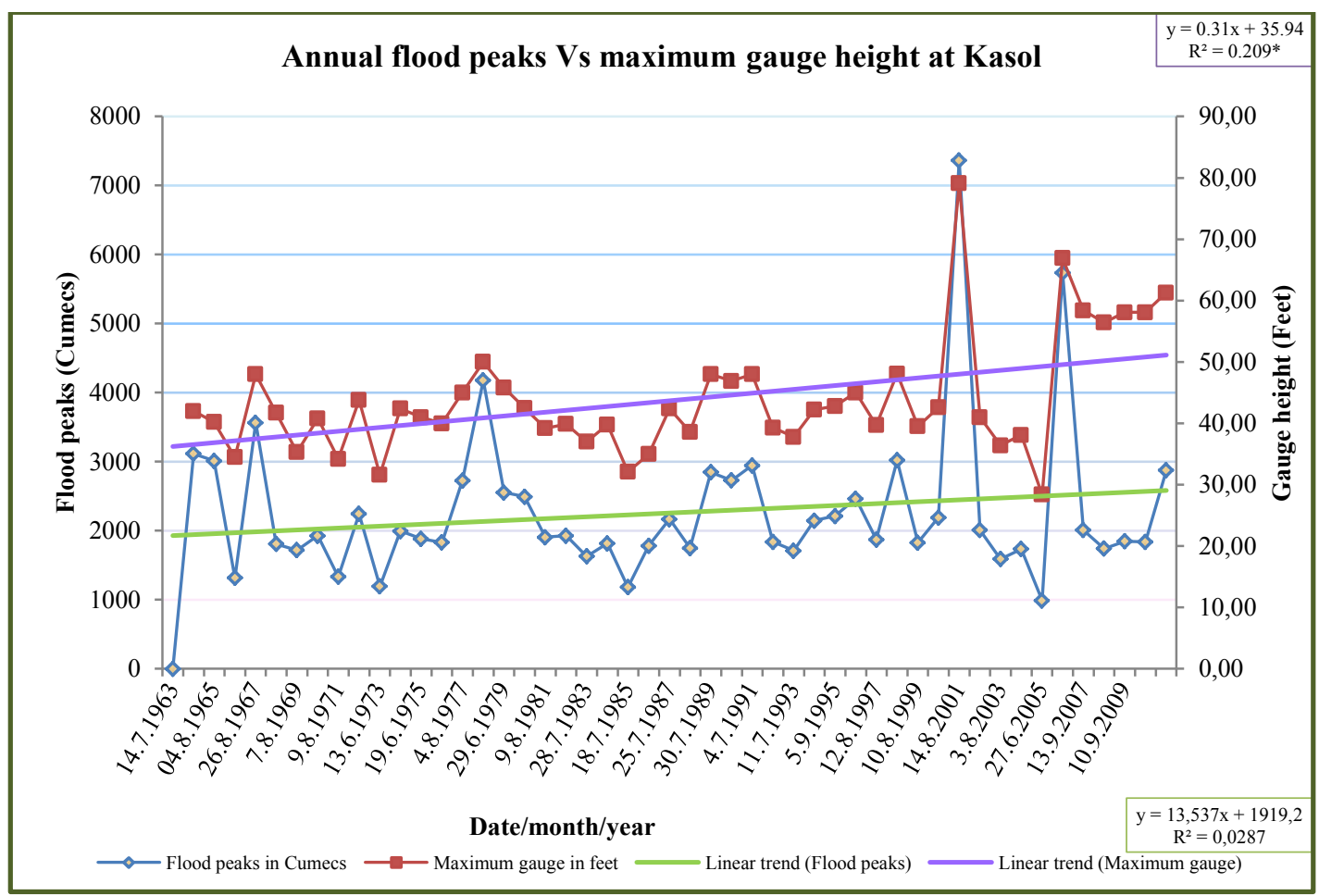

Figure 10. Time series plot for annual flood peaks and maximum gauge height at Kasol (*Significant at 95\% confidence level).

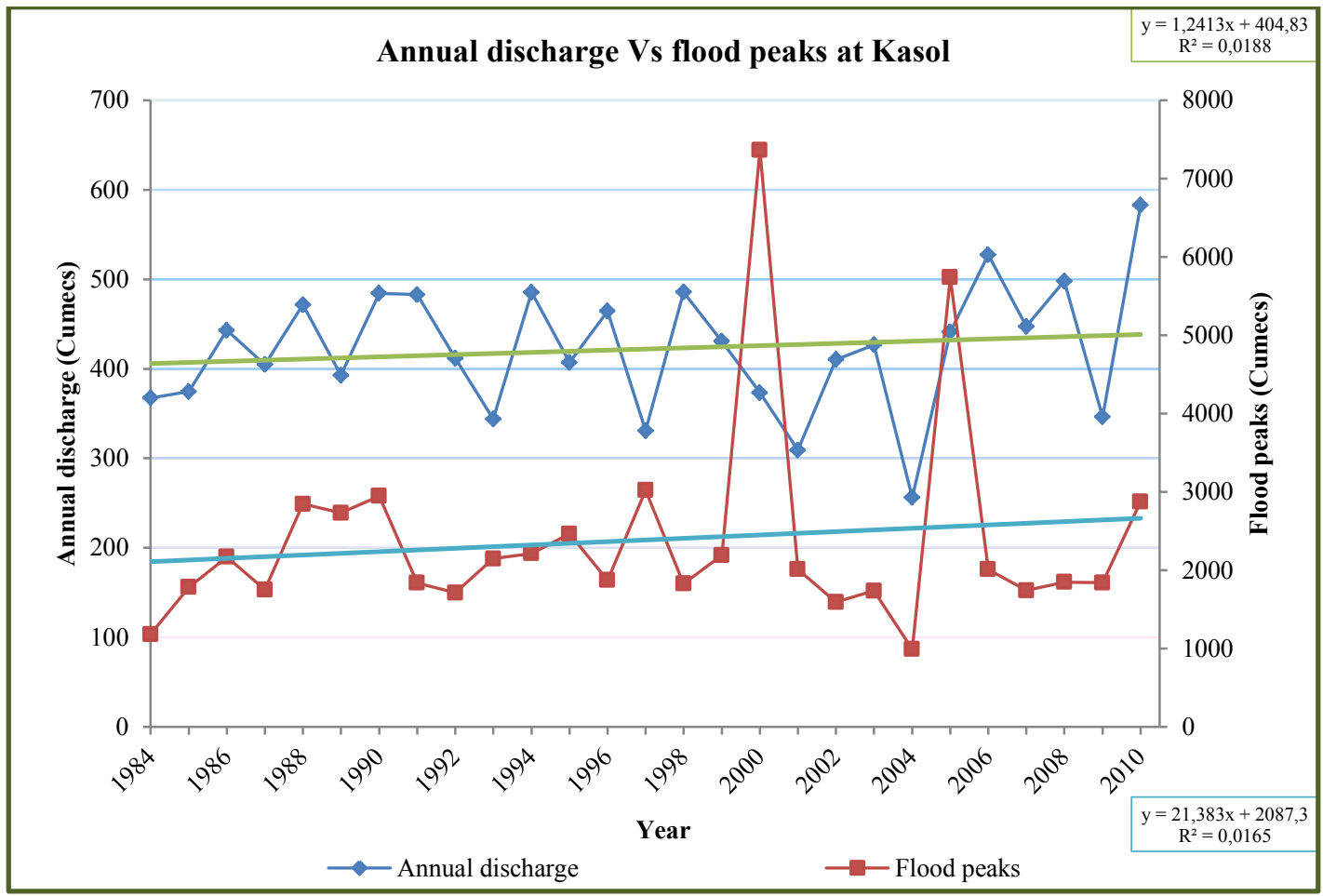

Figure 11. Comparison of annual discharge with flood peaks at Kasol. 


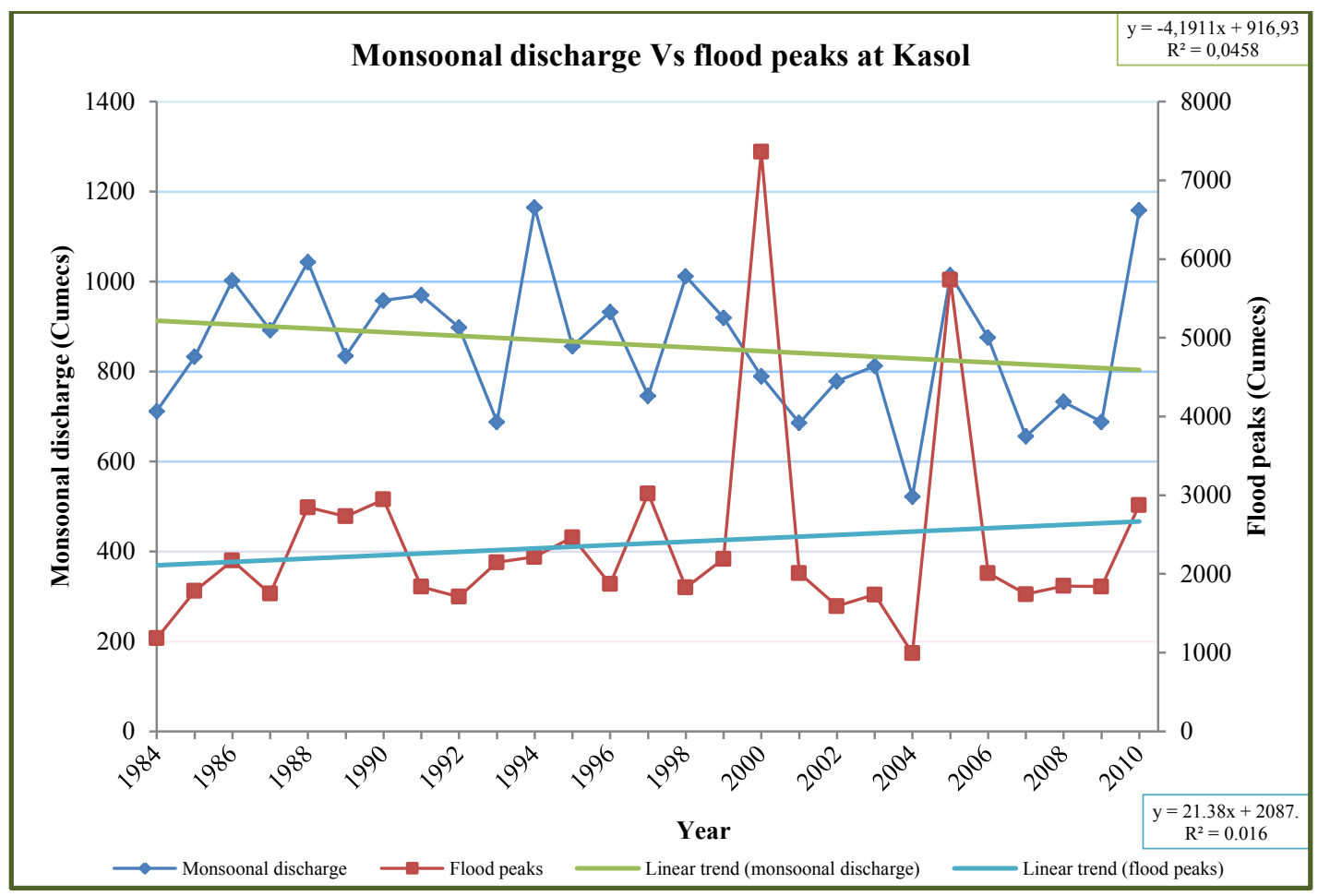

Figure 12. Comparison of monsoonal discharge with flood peaks at Kasol.

The analysis at Kasol site of Satluj River (Figure 10-12) shows that flood peaks and gauge heights are corresponding to each other and have increasing trend but the trend is significant in gauge height and insignificant in flood peaks. A comparison of annual and monsoonal average discharge with flood peaks was done. Annual average discharge and flood peaks show increasing trends which are statistically insignificant. The monsoonal average discharge shows the statistically insignificant decreasing trend, while the flood peak analysis indicates increasing but statistically insignificant trend.

Table 2. Results of trend analysis of flood peaks and gauge height in Satluj River Basin.

\section{S. No. Station Trend analysis}

\section{Mann-Kendall}

Linear regression

Flood peak Gauge height Glood peak Gauge height

\begin{tabular}{lllll}
\hline 1. Rampur & $+(0.72)$ & $+(0.48)$ & $+(0.70)$ & $+(0.34)$ \\
2. Suni & $+(0.84)$ & $+(0.71)$ & $+(0.29)$ & $+(0.23)$ \\
3. Kasol & $+(0.99)$ & $+(0.02)^{*}$ & $+(0.47)$ & $+(0.01)^{*}$ \\
\hline
\end{tabular}

*Significance at 95\% confidence level. (+) increasing, (-) decreasing.

The trend analysis results (Table 2) of flood peaks and gauge heights by non-parametric MannKendall and parametric linear regression tests indicate that the flood peaks at all sites i.e. Rampur, Suni and Kasol show increasing but statistically insignificant trends. The trends in gauge height at all sites are also showing increasing trend but Kasolis statistically significant at $95 \%$ confidence level.

The trends found by the linear regression were almost similar to the trends found by the MannKendall test. There were $100 \%$ increasing trends in both flood peaks and gauge heights but only gauge height of Kasol was significant at 95\% confidence level. Ironically, the precipitation, coupled 
with increasing temperature may cause further increase in the component of glacier-melt and also enhance flood peaks which indicate a direct relationship between climate change and annual flood peak discharges. The river experiences the peak discharge value in July and August which is essentially contributed by monsoon rainfall in the lower part of basin apart from snow and glacier meltdown. The correlation between the annual as well as monsoonal flow was negative implying that decrease in discharge value can not be expected to be associated with decreasing flood peaks. This may be due to decreasing contribution to flow from melting of snow and glaciers; and increasing contribution from incessant and spurt rainfall during monsoon season. But the relation between annual discharge and flood peaks at Kasol site showed exceptional trends.

The fast melting of glaciers, incessant monsoon rainfall and the synchronisation of the discharge peaks are the main causes of river floods. The impacts of climatic change on the Satluj River Basin where decreased contribution from glacier melt, irregular precipitation, and increased intensity and frequency of the flood peaks, likely became obstacles to the sustainable development of a lifesustaining system. Potential climate change related extreme events could intensify fragility of mountainous system where human activities lead to increased risk, resulting in greater sensitivity to climate change. Hydrological analysis of projected future climate change shows considerable changes in the frequency of peak discharges of rivers (IPCC, 2007b) which indicates future changes in risk. Damages from weather related disasters are projected to increase, due to a combination of increasing exposure of people and assets, and expected changes in the global climate.

Rapid and frequent changes in the discharge reduce the resistance of river bank to erosion. There has been disastrous erosion along the river due to extreme instability of the banks at several places. The high degree of instability in these areas makes them more vulnerable during flood season. Increasing flood peaks into river have cut and eroded the banks dangerously which in turn is threatening many habitations and other infrastructure. National Highway 22 that runs along the river is getting unstable at several places and the bridges are also under threat. The identification and quantification of historical peak discharge data provides answers to the questions like whether the frequency and magnitude of extreme events have increased or not during the past few decades, in relation to climatic variability. The sensitivity of flood peak variations provides important insight regarding the responses and vulnerability of different areas to climate change. The influence of climate change on such hydrologic processes, especially in mountain basins is paramount for understanding, forecasting and mitigating water related hazards.

\section{Conclusions}

Trend analysis of historical data concluded that the spatial and temporal variations in flood peak are due to climate change. The impacts of an intensification of flood peaks, most remarkably in connection with the possibility of an increasing occurrence of extreme events will adversely affect the people living downstream of such mountainous river. Studying the past flood peaks will help us to observe the frequency of occurrence of floods in certain region and to determine whether the flood peaks in the past have been same with that of the present or whether there is any deviation in the trend in relation to climate change. Information from trend analysis will be useful in the planning, development and management of water resources in the study area. Densification of observation stations, along with detailed study of climate change induced extreme events will further strengthen the formulation of future strategy for adaptation and mitigation.

\section{Acknowledgements}

Authors are thankful to Indian Council of Medical Research (ICMR) and University Grant Commission (UGC), New Delhi for providing financial assistance in the form of research fellowship. 


\section{References}

[1] S.K. Bartarya, N.S. Virdi, M.P. Sah (1996) Landslide hazards: Some case studies from the Satluj Valley, Himachal Pradesh: Himalayan Geology, 17: 193-207.

[2] M. Bayazit, B. Önöz (2007) To pre-whiten or not to pre-whiten in trend analysis? Hydrological Sciences Journal, 52 (4): 611-624.

[3] M.R. Bhutiyani, V.S. Kale, N.J. Pawar (2008) Changing streamflow patterns in the rivers of northwestern Himalaya: Implications of global warming in the $20^{\text {th }}$ century, Current Science, 95 (5): 618-626.

[4] D.H. Burn (1994) Hydrologic effects of climatic change in West-Central Canada, Journal of Hydrology, 160: 53-70.

[5] D.H. Burn, M.A. Hag Elnur (2002) Detection of hydrologic trends and variability, Journal of Hydrology, 255: 107-122.

[6] D.H. Burn, J.M. Cunderlik, A. Pietroniro (2004) Hydrological trends and variability in the Liard river basin, Hydrological Science Journal, 49: 53-67.

[7] A. Coudrain, B. Francou, Z.W. Kundzewick (2005) Glacier shrinkage in the Andes and consequences for water resources, Hydrological Sciences Journal, 50: 925-932.

[8] D.R. Cox, A. Stuart (1955) Some quick sign tests for trend in location and dispersion, Biometrika, 42: 80-95.

[9] J.M. Cunderlik, S.P. Simonovic (2005) Hydrological extremes in a southwestern Ontario river basin under future climate conditions, Hydrological Sciences Journal, 50: 631-654.

[10] E.J. Dietz, T.J. Killeen (1981) A nonparametric multivariate test for monotone trend with pharmaceutical applications, Journal of the American Statistical Association, 76: 169-174.

[11] E.M. Douglas, R.M. Vogel, C.N. Knoll (2000) Trends in flood and low flows in the United States: impact of spatial correlation, Journal of Hydrology, 240: 90-105.

[12] R.O. Gilbert (1987) Statistical methods for environmental pollution monitoring, Van Nostrand Reinhold, New York.

[13] V. Gupta, M.P. Sah, N.S. Virdi, S.K. Bartarya (1994) Landslide hazard zonation in the Upper Satluj Valley, District. Kinnaur, Himachal Pradesh, Journal of Himalayan Geology, 4(1): 81-93.

[14] J.P. Hamilton, G.S. Whitelaw, A. Fenech (2001) Mean annual temperature and annual precipitation trends at Canadian biosphere reserves, Environmental Monitoring and Assessment 67: 239-275.

[15] D.R. Helsel, R.M. Hirsch (1992) Statistical Methods in Water Resources, Elsevier, New York.

[16] R.M. Hirsch, J.R. Slack (1984) Non-parametric trend test for seasonal data with serial dependence, Water Resources Research, 20(6): 727-732.

[17] R.M. Hirsch, J.R. Slack, R.A. Smith (1982) Techniques of trend analysis for monthly water quality data, Water Resources Research, 18: 107-121.

[18] M.G. Kendall (1975) Rank Correlation Methods, Griffin, London.

[19] Z.W. Kundzewicz, U. Ulbrich, T. Brücher, D. Graczyk, A. Krüger, G. Leckebusch, L. Menzel, I. Pínskwar, M. Radziejewski, M. Swzed (2005) Summer floods in Central Europe: climate change track? Natural Hazards, 36: 165-189.

[20] Z. Li, F. Zheng, W. Liu, D.C. Flanagan (2010) Spatial distribution and temporal trends of extreme temperature and precipitation events on the Loess Plateau of China during 1961-2007, Quaternary International, 226: 92-100.

[21] A. Loukas, L. Vasiliades, N.R. Dalezios (2004) Climate change implications on flood response of a mountainous watershed, Water, Air and Soil Pollution, 4: 331-347. 
[22] H.B. Mann (1945) Nonparametric tests against trend, Econometrica 13: 245-259.

[23] P.C.D. Milly, R.T. Wetherald, K.A. Dunne, T.L. Delworth (2002) Increasing risk of great floods in a changing climate, Nature, 415: 514-517.

[24] M.M.Q. Mirza (2002) Global warning and changes in the probability of floods in Bangladesh and implication, Global Environmental Change, 12(2): 127-138.

[25] E.V. Novotny, H.G. Stefan (2007) Stream flow in Minnesota: Indicator of climate change, Journal of Hydrology, 334: 319- 333.

[26] T. Partal, E. Kahya (2006) Trend analysis in Turkish precipitation data, Hydrological Processes, 20: 2011-2026.

[27] J.D. Salas (1992) Analysis and modeling of hydrologic time series, In: Handbook of Hydrology, Maidment DR (ed). McGraw-Hill: New York, 19.1-19.72.

[28] Y. Shang, Z. Yang, L. Li, D. Liu, Q. Liao, Y. Wang (2003) A super-large landslide in Tibet in 2000: background, occurrence, disaster and origin, Geomorphology, 54: 225-243.

[29] H. Tabari, S. Marofi (2010) Changes of pan evaporation in the West of Iran, Water Resources Management, doi: 10.1007/s11269-010-9689-6.

[30] H. Tabari, S. Marofi, M. Ahmadi (2010a) Long-term variations of water quality parameters in the Maroon River, Iran, Environmental Monitoring and Assessment, doi: 10.1007/s10661-010$1633-y$.

[31] H. Tabari, S. Marofi, P. Hosseinzadeh Talaee, K. Mohammadi (2010b) Trend analysis of reference evapotranspiration in the western half of Iran, Agricultural and Forest Meteorology, doi: 10.1016/j.agrformet.2010.09.009.

[32] D. Viviroli, D.R. Archer, D. Buytaert, H.J. Fowler, G.W. Greenwood, A.F. Hamlet, Y. Huang, G. Koboltschnig, M.I. Litaor, J.I. L'opez-Moreno, S. Lorentz, B. Sch“adler, K. Schwaiger, M. Vuille, R. Woods (2010) Climate change and mountain water resources: overview and recommendations for research, management and politics, Hydrology and Earth System Sciences, 7: 2829-2895.

[33] H. Von Storch (1995) Misuses of Statistical Analysis in Climate Research, In: Von Storch H and Navarra A (eds.), Analysis of Climate Variability: Applications of Statistical Techniques. Springer-Verlag, Berlin, pp. 11-26.

[34] H. Von Storch, A. Navarra (1995) Analysis of Climate Variability - Applications of Statistical Techniques, Springer-Verlag: New York.

[35] Y.S. Yu, S. Zou, D. Whittemore (1993) Non-parametric trend analysis of water quality data of rivers in Kansas, Journal of Hydrology, 150: 61-80.

[36] S. Yue, P. Pilon (2004) A comparison of the power of the $t$ test, Mann-Kendall and bootstrap tests for trend detection, Hydrological Sciences Journal-des Sciences Hydrologiques, 49(1): 2137.

[37] S. Yue, C. Wang (2004) The Mann-Kendall Test Modified by Effective Sample Size to Detect Trend in Serially Correlated Hydrological Series, Water Resources Management, 18: 201-218.

[38] S. Yue, P. Pilon, P. Phinney (2003) Canadian streamflow trend detection: impacts of serial and cross-correlation, Hydrological Science Journal, 48(1):51-63.

[39] W. Zhang, Y. Yan, J. Zheng, L. Li, X. Dong, H. Cai (2009) Temporal and spatial variability of annual extreme water level in the Pearl River Delta region, China, Global and Planetary Change, 69: 35-47. 